\title{
Korelasi Kadar Serum Leptin dengan Aterosklerosis pada Pasien Systemic Lupus Erythematosus Wanita
}

\author{
Andi Manaek ${ }^{1}$, Gede Kambayana $^{1}$
}

1Program Studi Pendidikan Dokter Spesialis IImu Penyakit Dalam Fakultas Kedokteran Universitas Udayana / Rumah Sakit Umum Pusat Sanglah, Denpasar

Tanggal diterima : 2 Februari 2017 Tanggal Disetujui : 15 Februari 2017 Tanggal Diterbitkan : 20 Februari 2017
Penyakit kardiovaskular adalah penyebab kematian tertinggi di dunia. SLE diduga berkontribusi kuat mempercepat timbulnya aterosklerosis. Baru-baru ini, banyak bukti ditemukan berhubung dengan efek hormon pada sistem imun termasuk efeknya pada penyakit autoimun. Leptin dikenal sebagai hormon yang menyerupai sitokin dengan aksi pleiotropik dalam memodulasi respon imun. Penelitian yang dilakukan sebelumnya mendapatkan level leptin yang tinggi pada pasien SLE dengan plak aterosklerosis namun berkorelasi lemah dengan carotid Intima Media Thickness (cIMT). Tujuan penelitian ini yaitu untuk mengetahui korelasi serum leptin dengan aterosklerosis pada pasien SLE. Penelitian dilakukan dengan disain analitik potong lintang. Pengambilan sampel dilakukan dengan metode simple sampling. Konsentrasi serum leptin diperiksa dengan menggunakan metode ELISA dan aterosklerosis diperiksa dengan mesin Duplex carotid-intima Doppler Ultrasound oleh satu orang dokter spesialis radiologi. Analisis statistik menggunakan uji korelasi Spearman. Tingkat kemaknaan jika $p<0,05$. Sebanyak 54 orang pasien SLE wanita diikutkan dalam penelitian. Rerata kadar serum leptin adalah $203,83 \pm 179,06 \mathrm{ng} / \mathrm{ml}$. Pada pasien didapatkan rerata CIMT adalah $0,48 \pm 0,12 \mathrm{~mm}$ dengan frekuensi yang mendapat plak 5,5\% dan tidak plak $92,7 \%$. Terdapat korelasi lemah antara kadar serum leptin dengan aterosklerosis dalam hal ini yaitu CIMT $(r=0,028 ; p=0,843)$ dan plak $(r=0,008 ; p$ $=0,955)$, tetapi secara statistik tidak bermakna $(p<0,05)$. Pada penelitian ini tidak didapatkan korelasi antara kadar serum leptin dengan aterosklerosis pada pasien SLE wanita.

Kata kunci: aterosklerosis, leptin, CIMT, plak, SLE

Cardiovascular disease is the leading cause of death in the world. Allegedly, SLE contribute to accelerate the onset of atherosclerosis. Recently, a lot of evidence was found in connection between atherosclerosis and the effects of hormones on the immune system, including its effect on autoimmune disease. Leptin is known as hormone-like cytokine with pleiotropic action in modulating the immune response. Previous research carried out that obtain high leptin levels in SLE patients with atherosclerotic plaques, but the leptin levels weakly correlated with Carotid Intima Media Thickness (CIMT). Aim of this research to determine the correlation of serum leptin with atherosclerosis in patients with SLE. The study was conducted with a cross-sectional analytical design. Sampling was done by simple sampling method. Serum leptin concentrations examined using ELISA method and atherosclerosis are checked by machine Duplex Doppler Ultrasound of the carotid-intima by one person radiologist doctor. Statistical analysis is using Spearman correlation test. Significance is determined with $p<0.05$. A total of 54 female SLE patients included in the study. The mean levels of serum leptin were $203.83 \pm 179.06 \mathrm{ng} / \mathrm{ml}$. In the patients, whose mean CIMT was $0.48 \pm 0.12 \mathrm{~mm}$, percentage that gets plaques is $5.5 \%$ and without plaques $92.7 \%$. There is a weak correlation between serum leptin levels and atherosclerosis, in this case that CIMT ( $r=0.028 ; p=0.843)$ and plaque $(r=0.008 ; p=0.955)$, but was not statistically significant $(p<0.05)$. In this research, there is no correlation between serum leptin levels and atherosclerosis in SLE women.

Keywords: atherosclerosis, leptin, CIMT, plaque, SLE

\section{PENDAHULUAN}

Dalam 30 tahun terakhir, SLE telah menjadi salah satu penyakit reumatik utama di dunia. Prevalensi SLE diberbagai negara sangat bervariasi antara 2,9/100.000-400/100.000. SLE lebih sering ditemukan pada ras tertentu seperi bangsa Negro, Cina dan mungkin juga Filipina. Penyakit ini dapat ditemukan pada semua usia, tetapi paling banyak pada usia 15-40 tahun (masa reproduksi). Frekuensi pada wanita dibandingkan dengan frekuensi pada pria berkisar antara (5,5-9):1. Pada
SLE yang disebabkan obat, rasio ini lebih rendah, yaitu 3:2. ${ }^{1}$ Peningkatan risiko kardiovaskular pada pasien-pasien dengan SLE pertama kali dilaporkan tahun 1976, kematian yang terjadi kurang dari 1 tahun setelah onset SLE, biasanya berhubungan dengan aktifitas penyakit SLE, sedangkan pada pasien-pasien dengan perjalanan penyakit yang lebih lama, kematian berhubungan dengan penyakit kardiovaskular. Risiko miokard infark pada pasien-pasien dengan SLE 10 kali lebih besar daripada populasi umum meskipun setelah terhitung 
faktor-faktor risiko tradisional dari Framingham. Risiko ini ditemukan lebih nyata pada wanita dengan SLE dengan umur 35-44 tahun, yang 50 kali mendapat miokard infark dibandingkan dengan kontrol. ${ }^{2}$ Kejadian cepat timbulnya penyakit kardiovaskular merupakan perhatian utama bagi banyak pasien SLE. Kejadian kardiovaskular lebih sering dan lebih dini pada pasien-pasien SLE dibandingkan dengan individu-individu sehat. Faktor-faktor risiko tradisional seperti perubahan profil lemak, penuaan, dan merokok tidak menjelaskan secara penuh peningkatan risiko kardiovaskular. Autoimunitas diduga mempunyai peraran penting dalam mempercepat timbulnya aterosklerosis. Perubahan fungsi sistem imun disadari sebagai penyumbang utama dalam inisiasi dan progresi aterosklerosis. ${ }^{2}$

Aterosklerosis adalah suatu proses imuno-inflamasi kronis dan fibroproliferasi dari arteri ukuran sedang dan besar yang dicetuskan oleh lemak. Proses aterosklerosis dimulai pada satu lesi endotel yang mulai kehilangan fungsinya dan mengalami kebocoran. Lama kelamaan, sel-sel endotel tersebut mengalami kematian dan terjadilah proses deendotelialisasi, baik dengan maupun tanpa sel-sel trombosit menempel pada jaringan subendotelial yang terpapar. ${ }^{3}$

Percepatan timbulnya aterosklerosis lebih sering pada wanita muda dengan SLE dibandingkan populasi umum. Faktor risiko tradisional pada penyakit jantung tidak dapat menjelaskan insiden tinggi aterosklerosis pada SLE. Baru-baru ini, banyak bukti ditemukan berhubung dengan efek hormon pada sistem imun termasuk efeknya pada autoimun. Salah satu hormon yang berhubungan dengan disfungsi endotel ialah leptin. ${ }^{4}$ Leptin adalah suatu hormon yang dibentuk dari jaringan adiposa yang mengikat pada suatu reseptor yang merupakan suatu anggota dari kelas sitokin reseptor family. ${ }^{5}$ Leptin, suatu hormon peptide, memainkan peranan penting pada pengaturan berat badan, fungsi endokrin, reproduksi, respon imun, dan inflamasi. Sistem imun memodifikasi produksi leptin. Leptin memodulasi imunitas didapat dengan memperpanjang kelangsungan hidup sel $\mathrm{T}$ dan menstimulasinya untuk memproduksi sitokin proinflamasi dan juga mencegah apoptosis sel $\mathrm{T}$ yang diinduksi oleh kortikosteroid dan meningkatkan jumlah sel B pada darah. ${ }^{6}$ Faktor-faktor yang meningkatkan kadar leptin antara lain: obesitas, makan berlebihan, gagal ginjal tahap akhir, estrogen dan alkohol, sedangkan yang menurunkan kadar leptin selain yang sudah disebutkan diatas adalah : merokok, asam lemak bebas dan puasa. ${ }^{7,8}$

Level leptin yang tinggi menolong untuk mengidentifikasi pasien-pasien SLE dengan risiko aterosklerosis. Ini juga menjadi bukti bahwa inflamasi dan mekanisme imun memainkan peranan penting pada patogenesis aterosklerosis dalam SLE dan suatu metode baru dibutuhkan untuk memprediksi pasien-pasien SLE dengan risiko kardiovaskular.' Penelitian Garcia-Gonzales et al. (2002) mendapatkan konsentrasi leptin serum pada penderita SLE lebih tinggi dibandingkan dengan kontrol sehat ( $\mathrm{p} 0,023)$. Pada studi ini, level leptin tidak berkorelasi dengan umur, skor Mex-SLEDAI, dosis prednison dan lamanya menderita sakit dan juga tidak berkorelasi dengan titer anti-dsDNA. Studi ini juga tidak menemukan korelasi leptin dengan obat-obatan seperti prednison, klorokuin, atau obat-obat imunosupresif dan dosis prednisone. ${ }^{5}$

Beberapa studi potong lintang yang menggunakan ultrasonografi untuk menilai plak karotid sebagai surrogate marker dari aterosklerosis subklinikal, melaporkan bahwa plak aterosklerosis di pembuluh darah karotid mengalami peningkatan lebih dari 2 kali pada pasien-pasien dengan SLE dibandingkan dengan individu-individu tanpa SLE. Selanjutnya lebih dari 3 kali diantara pasien-pasien SLE dibandingkan dengan kontrol sehat memiliki kalsifikasi arteri koroner yang diperiksa dengan electron-beam CT. Selain itu, pada pemeriksaan yang menggunakan dua isotop single photon emission CT (SPECT) untuk menilai perfusi miokard, dilaporkan 40\% pasien dengan SLE ditemukan defek pada perfusi yang mengindikasi aterosklerosis subklinikal. ${ }^{2}$

Studi-studi yang meneliti aterosklerosis pada SLE menggunakan ultrasonografi carotid intima-media thicknes (CIMT) untuk menegakkan diagnosis aterosklerosis subklinis menjelaskan bahwa prevalensi plak karotis pada pasien SLE dua kali lebih besar dari kontrol. Progresivitas plak disebutkan pula sangat cepat. Kerusakan dinding pembuluh darah yang sangat cepat pada pasien SLE banyak dipengaruhi juga oleh tidak efektifnya repair mechanism. ${ }^{10}$ Diagnosis aterosklerosis dini ditegakkan dengan mengukur rerata ketebalan tunika intima-media arteri karotis. Pengukuran ketebalan tunika intima-media dilakukan pada kedua sisi arteri karotis pada beberapa titik di tiap sisi. Pada Penelitian Maureen McMahon et al. (2011), menunjukkan bahwa 41,9\% pasien SLE dengan plak memiliki level leptin yang tinggi dibandingkan dengan $20,8 \%$ pasien SLE tanpa plak $(\mathrm{p}=0,003)$. Satu-satunya yang signifikan yang berasosiasi dengan penderita SLE dengan plak ialah leptin dengan kuartil tertinggi ( $\geq 29,5 \mathrm{ng} / \mathrm{ml})(\mathrm{OR}=2,8$ $\mathrm{p}=0,03)$ dibandingkan dengan proinflamasi $\mathrm{HDL}(\mathrm{OR}=12,8$ $\mathrm{p}<0,001)$, umur $(\mathrm{OR}=1,1 \mathrm{p}<0,001)$, merokok $(\mathrm{OR}=7,7 \mathrm{p}=0,03)$ dan hipertensi $(O R=3,0 \mathrm{p}=0,01)$. Pada studi ini level leptin berkorelasi lemah dengan CIMT $(r=0,14 \mathrm{p}=0,03)^{9}$.

Tujuan penelitian ini yaitu untuk mengetahui korelasi serum leptin dengan aterosklerosis pada pasien SLE. Dengan mengetahui korelasi serum leptin dengan aterosklerosis pada pasien SLE maka menambah pengetahuan tentang peranan serum leptin dalam proses pembentukan aterosklerosis pada pasien SLE, disamping dapat dijadikan data dasar untuk 
penelitian selanjutnya terutama kaitannya kemungkinan penggunaan antagonis leptin dalam penanganan aterosklerosis pada pasien SLE.

\section{METODE}

Penelitian dilakukan dengan disain analitik potong lintang. Pengambilan sampel dilakukan dengan metode simple sampling. Sebanyak 54 orang pasien SLE wanita diikutkan dalam penelitian. Konsentrasi serum leptin diperiksa dengan menggunakan metode ELISA dan aterosklerosis diperiksa dengan mesin Duplex carotid-intima Doppler Ultrasound oleh satu orang dokter spesialis radiologi.

\section{HASIL DAN PEMBAHASAN}

Sebanyak 54 sampel yang diperiksa dengan rentang umur pasien adalah 33,44 $\pm 10,76$ tahun dan rerata IMT pasien adalah 20,49 $\pm 3,98 \mathrm{~kg} / \mathrm{m} 2$. Durasi sakit bervariasi antara 3 bulan hingga 168 bulan (14 tahun), Prevalensi dislipidemia

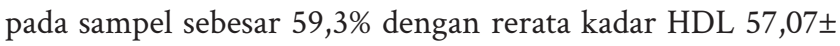
$15,69 \mathrm{mg} / \mathrm{dl}$; rerata kadar LDL 114,69 42,63 mg/dl; dan rentangan trigliserida $60-862 \mathrm{mg} / \mathrm{dl}$ dan kolesterol total 114-353 mg/dl. Semua pasien mempunyai kadar leptin yang melebihi nilai normal dengan nilai rerata $154,13 \mathrm{ng} / \mathrm{ml}$ (nilai normal leptin pada wanita 3,7-11,1 ng/ml). Pada rerata CIMT menunjukkan bahwa pada sampel memiliki rerata ukuran tunika intima-media masih dalam batas normal (kurang dari 0,9 mm), sebagian besar sampel pasien SLE tidak menunjukkan adanya plak, hanya 3 orang saja yang positif adanya plak.
Hubungan antara leptin dengan ateroklerosis diuji dengan analisis korelasi Spearman. Berdasarkan hasil analisis didapatkan bahwa nilai koefisien korelasi $(r)<0,20$ dan nilai $\mathrm{p}$ $>0,05$. Hal ini menunjukkan hubungan leptin dengan CIMT dan Plak didapatkan koefisien korelasi (r) 0,028 dan 0,008 dan nilai p > 0,05 untuk keduanya. Hal ini menunjukkan bahwa tidak terdapat korelasi antara kadar serum leptin dengan CIMT dan plak.

Berhubungan dengan peranan penting leptin pada penyakit autoimun, didapatkan bahwa perempuan mempunyai kadar leptin serum 2-3 kali lebih tinggi dibandingkan dengan laki-laki yang sudah disesuaikan dengan umur dan IMT. ${ }^{11}$ Maureen McMahon et al. (2011), dengan studi kohort diantara 250 pasien SLE dan 122 kontrol, setelah analisis bivariat ditunjukkan bahwa 41,9\% pasien SLE dengan plak memiliki level leptin yang tinggi dibandingkan dengan 20,8\% pasien SLE tanpa plak $(\mathrm{p}=0,003) .{ }^{4}$ Didukung hasil penelitian ini, bahwa tidak ada korelasi antara leptin dengan timbulnya aterosklerosis mungkin disebabkan karena terjadinya resistensi leptin. Pada konteks obesitas dan penyakit, resistensi leptin mengalami penurunan sensitivitas, peningkatan level dari leptin tetapi respon tidak adekuat. Mekanisme terjadinya resistensi leptin dapat terjadi karena mutasi genetik, selfregulation, akses jaringan yang terbatas, cellular, dan faktor di sirkulasi. Pada konteks obesitas dan penyakit, resistensi leptin mengalami penurunan sensitivitas, peningkatan level dari leptin tetapi respon tidak adekuat. Mekanisme terjadinya resistensi leptin dapat terjadi karena mutasi genetik, selfregulation, akses jaringan yang terbatas, cellular, dan faktor di sirkulasi. $^{12}$

\section{$(\mathrm{r})<0,20$ dan nilai $\mathrm{p}>0,05$.}

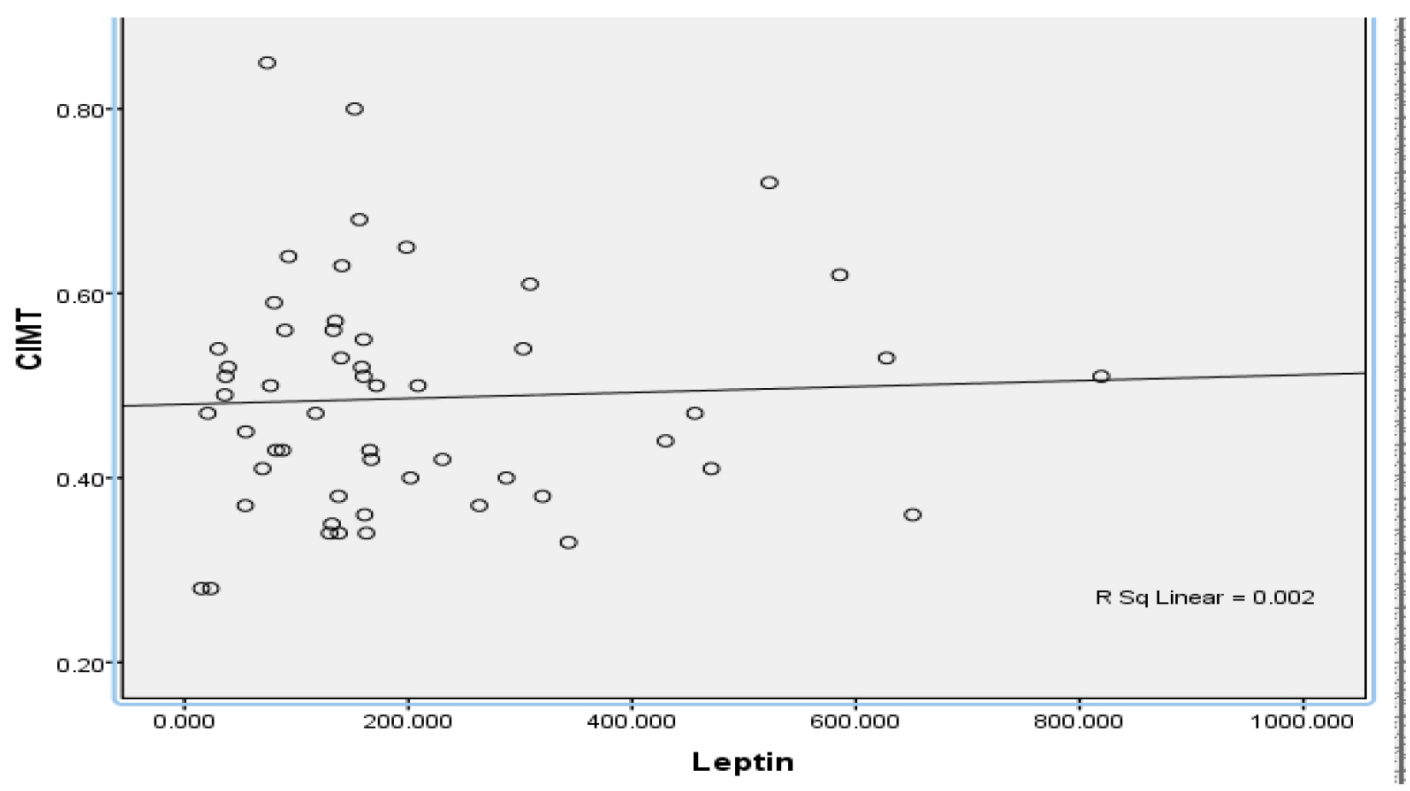

Gambar 1. Korelasi Leptin dengan Aterosklerosis 


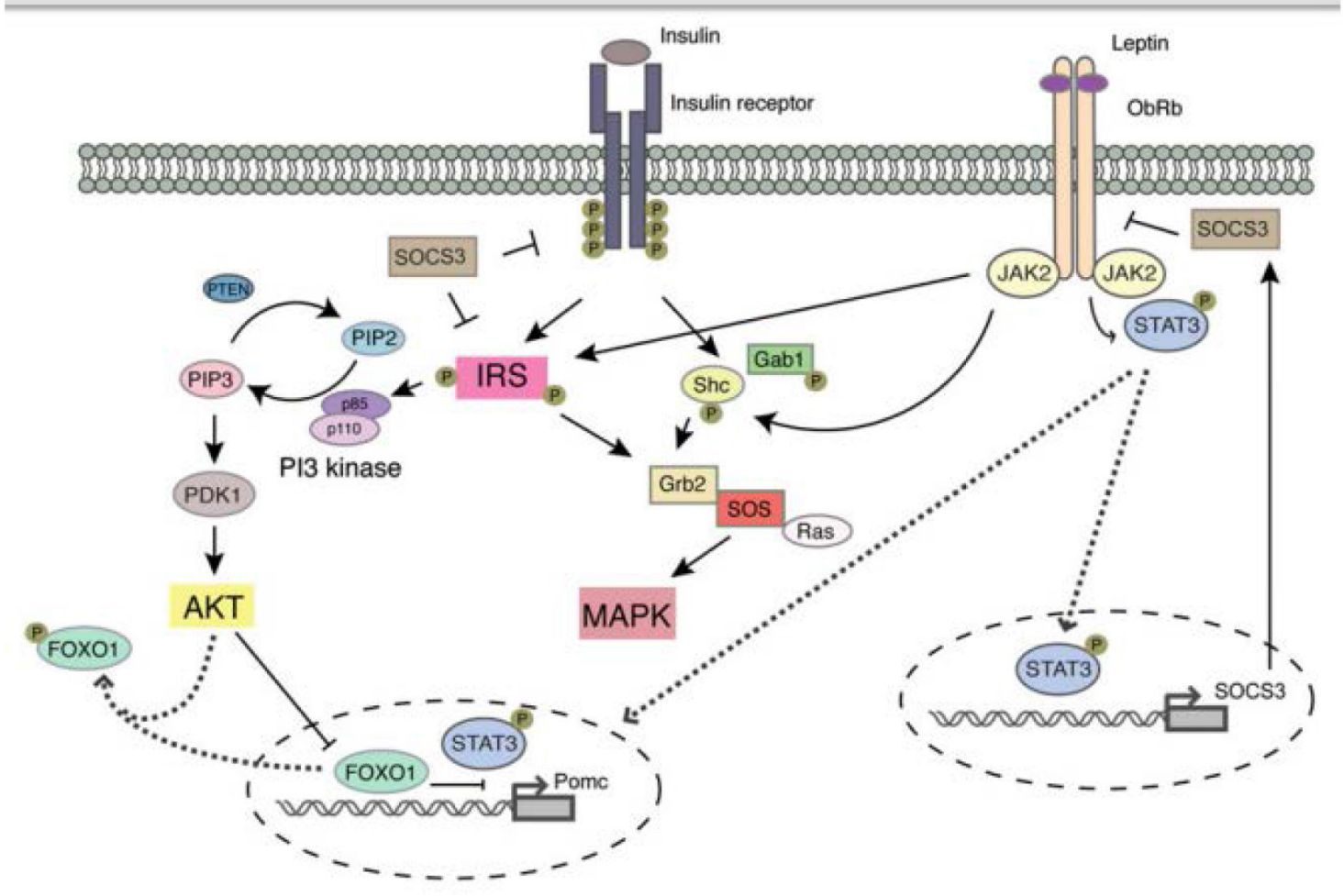

Gambar 2. Mekanisme Resistensi Leptin dan Insulin

Pada mutasi genetik, resistensi leptin dapat diturunkan secara genetik walaupun tidak umum. Mutasi genetik menghasilkan leptin tetapi tidak efektif dalam signaling, dapat menyebabkan hiperleptinemia dan resistensi leptin. Pada selfregulation, leptin memperlihatkan pengaturan reseptor sendiri dan signaling, dan pengaturan reseptor yang menurun akan memunculkan resistensi leptin. Pengurangan reseptor leptin di hipotalamaus akan memunculkan perusakan dari signaling leptin. Pengurangan ini secara langsung meningkatkan leptin di sentral yang dapat mendesensitisasi respon fisiologis selamanya.

Level leptin yang tinggi terlihat pada individu yang gemuk yang diduga pada pasien gemuk terjadi resistensi dari leptin yang mirip resistensi insulin, pada diabetes tipe II.9 Resistensi leptin berefek juga dengan timbulnya resistensi insulin. Hal ini juga dipengaruhi melalui efek peningkatan STAT 3 melalui mediasi dari SOCS 3 yang menghambat signaling baik leptin maupun insulin. ${ }^{13}$

\section{SIMPULAN}

Pada penelitian ini tidak didapatkan korelasi antara kadar serum leptin dengan aterosklerosis pada pasien SLE wanita. Keterbatasan pada penelitian potong lintang ini yaitu sulit untuk melakukan penilaian hubungan sebab akibat dan adanya bias insidens-prevalens juga bisa terjadi pada penelitian ini. Selain itu pengukuran konsentrasi leptin serum yang dilakukan hanya sekali tidak mencerminkan konsentrasi tersebut menetap dalam waktu yang lama. Untuk memperjelas peran resistensi leptin dalam proses tidak terjadinya aterosklerosis pada pasien SLE, diperlukan penelitian lebih lanjut untuk mencari mekanisme resistensi leptin yaitu melalui mutasi genetik, SOCS 3, SLIPs dan peranan resistensi insulin. Untuk penelitian berikutnya, pemeriksaan konsentrasi leptin serum dengan aterosklerosis perlu melibatkan kontrol sehat sebagai pembanding.

\section{DAFTAR PUSTAKA}

1. Isbagio H., Kasjmir Y.I., Setyohadi B., Suarjana N. 2009. Lupus Eritematosus Sistemik. Dalam: Sudoyo A.W., Setiyohadi B., Alwi I., Simadibrata M., Setiati S., penyunting. Buku Ajar Ilmu Penyakit Dalam Edisi Kelima. Jakarta: InternaPublishing, h.2565-2577.

2. Skaggs B.J., Hahn B.H., McMahon M. 2012. Accelerated atherosclerosis in patients with SLE-mechanisms and management. Nat Rev Rheumatol, 8: 214-223.

3. Tanubudi D. Patofisiologi Aterosklerosis. Dalam: Rahasto P., Priatna H., penyunting. Aterosklerosis dan Trombosis. Banten: PERKI, h.21-29. 


\section{ARTIKEL ASLI}

Jurnal Penyakit Dalam Udayana

Udayana Journal of Internal Medicine

Volume 1, No 1: 2017

Print ISSN: 2580-2925

Online ISSN: 2580-2933

4. Mcmahon M., Skaggs B.J., Sahakian L., Grossman J., Fitzgerald J., Ragavendra N., Charles-Schoeman C., Chernishof M., Gorn A., Karpouzas G.A., Wong W.K., Weisman M., Wallace D.J., Taylor M.B., Watson K.F., Hahn B.H. 2014. A Panel of biomarkers is associated with increased risk of the presence and progression of atherosclerosis in women with systemic lupus erythematosus. Arthritis \& Rheumatology, 66(1): 130-139.

5. Garcia-Gonzales A., Gonzales-Lopez L., Valera-Gonzales I.C., Cardona-Munoz E.G., Salazar-Paramo M., GonzalesOrtiz M., et al. 2002. Serum Leptin levels in women with systemic lupus erythematosus. Rheumatol Int, 22: 138-141.

6. Wislowska M., Rok M., Stepien K., Kuklo-kowalska A. 2008. Serum leptin in systemic lupus erythematosus. Rheumatol Int, 28: 467-473.

7. Merabet E., Dagogo-Jack S., Coyne D.W., Klein S., Santiago J.V., Hmiel S.P., Landt M. 1997. Increased plasma leptin concentration in end-stage renal disease. $J$ Clin Endocrinol Metab, 82(3): 847-850.

8. Margetic S., Gazzola C., Pegg G.G., Hill R.A. 2002. Leptin: a review of its peripheral action and interactions. Int J Obes, 26: 1407-1433.
9. Mcmahon M., Skaggs B.J., Sahakian L., Grossman J., Fitzgerald J., Ragavendra N., Charles-Schoeman C., Chernishof M., Gorn A., Witztum J.L., Wong W.K., Weisman M., Wallace D.J., Cava A.L., Hahn B.H. 2011. High plasma leptin levels confer increased risk of atherosclerosis in women with systemic lupus erythematosus, and are associated with inflammatory oxidized lipids. Ann Rheum Dis, 70: 1619-1624.

10. Roman M.J. 2007. Rate and determinants of progression of atherosclerosis in systemic lupus erythematosus. Arthritis Rheum; 56.p. 3412-3419.

11. Lam Q.L.K.,Lu L. 2007. Role of Leptin in immunity. Cell Mol Immunol, 4(1): 1-13.

12. Martin S.S., Qasim A., Reilly M.P. 2008. Leptin Resistance. Journal of the American College of Cardiology, 52: 1201-1210

13. Konner A.C., Bruning J.C. 2012. Selective Insulin and Leptin Resistance in Metabolic Disorders. Cell Metabolism, 16: 146.

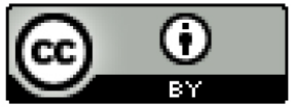

This work is licensed under a Creative Commons Attribution 4.0 International License. 